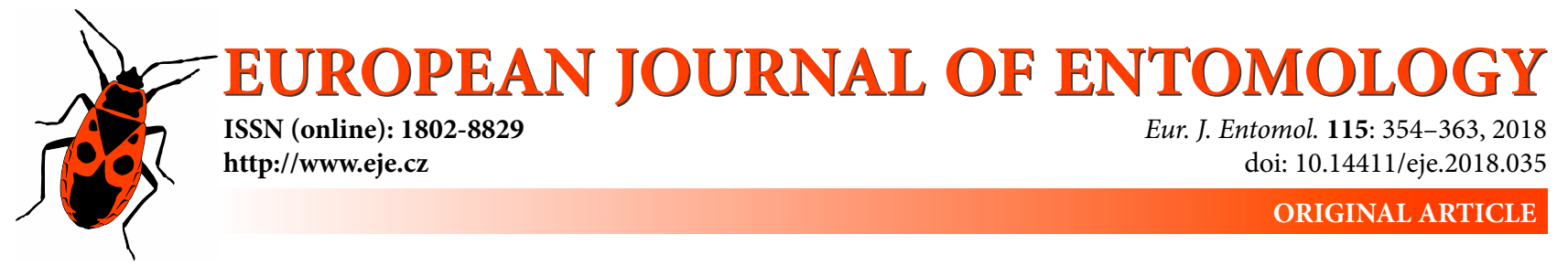

\title{
Diversity of insects associated with two common plants in the Brazilian Cerrado: Responses of two guilds of herbivores to bottom-up and top-down forces
}

\author{
Juliana KUCHENBECKER ${ }^{1,2}$ and MARCílio FAGUNDES ${ }^{2, *}$ \\ ${ }^{1}$ Laboratório de Ecologia de Insetos, DBG/ICB/Universidade Federal de Minas Gerais, Belo Horizonte, 30161-970, Brasil; \\ e-mails: jubelisario@gmail.com, marcilio.fagundes@gmail.com \\ ${ }^{2}$ Laboratório de Biologia da Conservação, DBG/CCBS/Universidade Estadual de Montes Claros, Montes Claros, Minas Gerais, \\ 39401-089, Brasil
}

Key words. Ant, $\beta$ diversity, herbivore, community organization, insect guilds, trophic cascade, vegetation heterogeneity

Abstract. The Trophic Cascade Theory has been used to explain the organization of herbivorous insect communities in tropical ecosystems. In addition, the insect community associated with a species of plant can also be determined by the geographical distribution and taxonomic isolation of the plant. In this study, the following predictions about the number of herbivores associated with particular host plants were tested: (i) plant species belonging to large taxonomic groups with broad geographical distributions have a higher number, (ii) the abundance of ants negatively affects herbivore insect diversity, (iii) local plant diversity positively affects chewing herbivore diversity and (iv) local abundance of a specific host plant positively affects the diversity of sucking herbivores. The samples of insect herbivores were collected from 32 plants (16 plants of Erythroxylum suberosum and 16 of Qualea parviflora) by beating. A total of 71 ants (13 species) and 158 herbivorous insects (90 species) were collected from these two species of plants. The richness and abundance of the insect herbivores collected from $E$. suberosum differed from those collected from Q. parviflora. The abundance of ants negatively affected the diversity of sucking insects associated with $E$. suberosum. In addition, the interaction between the variables total plant richness per plot and ant abundance affected the diversity of chewing insects associated with $E$. suberosum. The density of $Q$. parviflora per plot affected the diversity of associated sucking insects. In addition, the interaction of the variables abundance of ants and abundance of $Q$. parviflora influenced the diversity of chewing insects. Our results indicate that there is no predominance of bottom-up or top-down forces in the organization of herbivorous insect communities in this area of tropical savanna, but the roles of these forces on insect communities are guild-dependent.

\section{INTRODUCTION}

The Trophic Cascade Theory predicts that every trophic level is directly affected by the upper and lower trophic levels (Paine, 1980; Carpenter et al., 1985). This theory is used to explain the organization of communities of insect herbivores in ecosystems (Del-Claro, 2004; AbdalaRoberts et al., 2010; Scherber et al., 2010; Moon \& Silva, 2013). Many studies indicate that communities of insect herbivores are shaped by a top-down interaction (e.g. predation and parasitism) with the third trophic level (e.g. Vega et al., 2012; Hoog \& Daane, 2015) and by bottomup effects, such as chemical and physical plant defenses (e.g. Richards et al., 2015), plant architecture (e.g. LázaroGonzález, 2017) and vegetation heterogeneity (e.g. Moon \& Silva, 2013; Lin et al., 2015). In addition, recent studies have also shown that communities of insect herbivores can also be shaped by the interactions that occur at the same trophic level (Kaplan \& Denno, 2007; Cornelissen et al., 2013).

Vegetation heterogeneity (i.e. richness and abundance of plants) is considered to be a good predictor of the local diversity of insect herbivores, especially in tropical terrestrial ecosystems (Araújo et al., 2013; Leal et al., 2015; Nascimento et al., 2015). In general, the number of insect species is directly related to local vegetation heterogeneity (Root, 1973; McCoy et al., 1991; Scherber et al., 2010; Lin et al., 2015), but the lack of a relation (Coelho et al., 2017) or a negative relation between these variables have also been documented (Neves et al., 2012). In addition, the geographical distribution (Costa et al., 2011) and taxonomic isolation (Grandez-Rios et al., 2015) of a species of plant can affect the insect community associated with a plant.

\footnotetext{
* Corresponding and present address: Universidade Estadual de Montes Claros, Programa de Pós-Graduação em Biodiversidade, Departamento de Biologia Geral, Laboratório de Biologia da Conservação, Av. Ruy Braga s/n, Caixa postal 126, Montes Claros, Minas Gerais, 39401-089, Brazil; e-mail: marcilio.fagundes@gmail.com
} 
In general, species of plants that have a broad geographical distribution and belong to large genus or family have a greater diversity of herbivorous insects (Southwood, 1960; Grandez-Rios et al., 2015; Coelho et al., 2017).

Generalist predators can have a big effect on the organization of communities of insect herbivores in many different habitats (Dyer \& Letourneau, 1999; Del-Claro, 2004; Rosumek et al., 2009). Ants are dominant invertebrate predators in tropical and subtropical terrestrial ecosystems (Brady et al., 2014) and interact with a variety of animal and plant taxa (Del-Claro et al., 1996). For example, many species of ants that feed on extrafloral nectary or honeydew exuded by homopterans reduce herbivory by driving off herbivores or eating insect herbivores (Fagundes et al., 2005). In contrast, it is also possible that ants increase the numbers of some Homoptera by moving them to particular plants (Del-Claro, 2004; Neves et al., 2011). Therefore, ants are important elements of the third trophic level and are able to shape the community of insect herbivores on plants (Davidson et al., 2003; Heil \& McKey, 2003; Ribas et al., 2003; Fagundes et al., 2005; Rosumek et al., 2009). In addition, some studies also show that different insect food guilds respond differently to vegetation heterogeneity or third trophic level pressure (Grimbacher \& Stork, 2007; Neves et al., 2013; Leal et al., 2015).

In general, the sucking herbivore guild is considered more specialized in the use of food resources than the chewing herbivore guild (Neves et al., 2010, 2013; Forister et al., 2015) and sucking insects generally spend more time feeding on plants than chewing herbivores (Novotny et al., 2003; Ribeiro, 2003; Mody \& Linsenmair, 2004). In addition, the occurrence of specialist herbivores on a specific plant must be more dependent on the attributes of this plant because these herbivores have finer mechanisms for locating and feeding on plants (Ribeiro, 2003; Neves et al., 2011). On the other hand, habitats with high plant diversity should have a greater diversity of generalist insects (Novotny et al., 2002, 2006; Ricklefs \& Marquis, 2012). In this case, we expect that the diversity of chewing herbivores on a particular plant is more dependent on local plant species diversity whereas sucking insects are more affected by attributes of their host plant.

The Cerrado (Brazilian savannah) is the second biggest Brazilian biome and one of the global biodiversity hotspots (Myers et al., 2000; Silva \& Bates, 2002; Strassburg et al., 2017). Its biodiversity is one of the most diverse on this planet and no other savannah in the world has such species, shapes and functional richness (Fernandes et al., 2016). Recent estimates indicate that in the Cerrado biome there is approximately 13,140 species of plants, but its invertebrate fauna is not very well know (Fernandes, 2016). Invertebrates are of fundamental importance for the processes that structure terrestrial ecosystems (Wilson, 1987; Weisser \& Siemann, 2004; Prather et al., 2013), which accounts for the growing number of studies on invertebrate communities and the use of this data for the formulation and testing of different hypothesis.
In this study we compare the herbivore insect diversity associated with two species of plants common in the Cerrado and evaluate the responses of two guilds of insect herbivores associated with these plants to generalist predators and vegetation heterogeneity. Specifically we tested the following prediction: (i) plant species belonging to large taxonomic groups with a broad geographical distribution have a higher number of associated herbivores (ii) the abundance of ants negatively affects the richness and abundance of herbivorous insects on plants (iii) the local plant richness positively affects the chewing herbivore diversity associated with a host species and (iv) the local abundance of a particular host plant positively affects the associated diversity of sucking herbivores.

\section{MATERIAL AND METHODS}

\section{Study site}

This study was carried out in a protected area $(-17.215,-44.414$ UTM) of approximately 98 hectares located in the municipality of Jequitaí, northern Minas Gerais, Brazil. The dominant vegetation in the study area is the regenerating "sensu stricto" cerrado. Physiognomically, the area is in the transition zone between the Cerrado and Caatinga biomes (Costa et al., 2016) and has a semiarid climate with well defined dry and wet seasons. The average annual temperature is $23^{\circ} \mathrm{C}$ and precipitation is approximately $1000 \mathrm{~mm} /$ year, with the rain falling mostly from November to January (INMET, 2016).

\section{Plants studied}

The two species of plants used to test the proposed hypotheses occur sympatrically in the study area, and are similar in size and leaf phenology. Qualea parviflora Mart. (Vochysiaceae) is a deciduous species of Cerrado shrub-tree that can attain $2-8 \mathrm{~m}$ in height and remains leafless until the end of the dry season (Sajo \& Rudall, 2002). Q. parviflora is the second most common woody species in the Cerrado (Ratter et al., 2003). The Qualea genus is comprised of approximately 60 species, with a geographic distribution ranging from Central America to the state of Santa Catarina in Brazil, and is widely distributed in the Cerrado (Shimizu, 2009). Erythroxylum suberosum A. St.-Hil. (Erythroxylaceae) is a shrub or small tree that can be up to six meters in height. There are four genera in the Erythroxylaceae, but only Erythroxylum occurs in Brazil, especially in the Caatinga and Cerrado Biomes (Plowman \& Hensold, 2004). In the study area, leaf flushing of E. suberosum shrubs occurs in October-November and coincides with the first rains.

\section{Data collection}

During random walks in the study area, specific spots were located where at least one individual of Erythroxylum suberosum (Erythroxylaceae) and Qualea parviflora (Vochysiaceae) co-occurred within a distance of $10 \mathrm{~m}$ of one another. Later, a plot of $100 \mathrm{~m}^{2}(10 \mathrm{~m} \times 10 \mathrm{~m})$ was demarcated around each location. A total of 16 plots, at distances from each other of at least $50 \mathrm{~m}$, were delimited in the study area. Initially, all the plants with DBH (Diameter at Breast Height measured at $1.30 \mathrm{~m}$ from the soil) of $10 \mathrm{~cm}$ or greater were marked with metallic plates and had their DBH and height measured. Representative samples from these plants were collected for identification based on comparison with botanic collections, herbariums and by consulting specialists. By doing so, the richness and abundance of the plants in each plot were determined (see Table S1) and used as a measure of environmental heterogeneity. All species that were collected are now 
in the basic reference collection of the Rio Jequitaí Consorce Jequitaí Project.

In each plot, one individual of Erythroxylum suberosum and one individual of Qualea parviflora with DBHs of $10 \mathrm{~cm}$ or greater were arbitrarily chosen, totaling 32 plants for insect sampling. The herbivorous insects and ants were collected by beating and using an entomological umbrella to collect the dislodged insects (Neves et al., 2013). Three branches of similar size and shape of each plant were each beaten 10 times and the dislodged insects collected in the entomological umbrella. This was done in the morning from $8 \mathrm{~h}$ to $12 \mathrm{~h}$, in February, April and June 2016, that is, the beginning, middle and end of the wet season and when both species of plants have leaves. The sampled insects were properly conditioned in individual plastic containers and transported to the Laboratory of Conservation Biology where they were screened and identified. The insects collected were identified to family level using taxonomic keys and separated into morphospecies (see Leal et al., 2015). Then the herbivores were grouped into two guilds (sucking or chewing) according to their feeding habits (Neves et al., 2014).

\section{Data analysis}

In order to determine if the richness and abundance of insect herbivores on Erythroxylum suberosum and Qualea parviflora differed, Generalized Linear Mixed Models (GLMM's) were used. For this, the richness or abundance of the insect herbivores was used as responses variables and plant species as explanatory variables, assuming a Poisson distribution of data and treating the plot as a random factor. Finally, the significance of the models was tested by comparing original models with a null model using a chi-squared test. All statistical analyses were done using the lmer package in R software (R Development Core Team, 2015).

Multivariate analyses were used to test differences in the composition of the herbivorous insects on the two host plants. Firstly, samples were ordered using Non-metric Multidimensional Scaling (nMDS). For that, a matrix of the abundance of the species of herbivorous insects was constructed and the Euclidean distance index was used as dissimilarity metric. Then, a non-parametric permutation procedure (ANOSIM) was applied, using the Euclidean distance index with 5000 permutations, to test the significance of the groups formed in the nMDS (Hammer et al., 2001). The values of $P$ and $r$ were obtained and the similarity patterns between species of insect herbivores on the plants studied were determined. The analyses were developed using the software PAST (Hammer et al., 2001). Before these analyses, the abundance data of the insect herbivores were log-transformed.

In order to verify if the richness and the abundance of sucking or chewing insect herbivores associated with each plant were influenced by the local richness of plants (i.e. richness of plant species per plot), the abundance of the species of plants studied (i.e. E. suberosum or Q. parviflora) and abundance of ants on these plants, different Generalized Linear Models with the proper error distribution were created. Thus, eight different models were constructed using the richness or the abundance of sucking and chewing herbivorous insects as response variables. The abundance of ants per sampled plant, the richness of plant species per plot, the abundance of the focal plant species in the plot and the interactions among these variables were the explanatory variables. We tested the models using a chi-squared test based on the Poisson distribution as they contained count data. To control for the effect of the entry sequence of variables used in the models, we use a stepwise model selection analysis in the package MuMIn for R (Bartón, 2015). In this analysis, the selection of the most parsimonious model is based on the values of the Akaike Information Criterion (AIC). Finally, we submitted the most parsimonious model to an analysis of residues to test for the adequacy of the model to meet statistical assumptions. The analyses were made using $\mathrm{R}$ software (R Development Core Team, 2015).

\section{RESULTS}

\section{General patterns}

In this study, 71 individuals belonging to 12 species of ants were collected from Erythroxylum suberosum and Qualea parviflora. The most abundant species of ants were Crematogaster victim Smith and Camponotus blandus Smith, which made up, respectively, $36.62 \%$ and $18.31 \%$ of the total abundance of ants. The most frequent species were Camponotus blandus and Crematogaster victim, occurring respectively on $37.5 \%$ and $25 \%$ of the plants sampled (Table S2).

A total of 157 insect herbivores belonging to 29 families and 90 species were collected from E. suberosum and $Q$. parviflora (Table S3). Of this total, 117 were sucking and 40 chewing insects. Among the sucking herbivores, Cicadelidae and Tingidae were the richest in species and most abundant, while for the chewing insects the Chrysomelidae and Lepismatidae were the richest in species and most abundant.

The richness $($ Chisq $=16.175 ; \mathrm{P}<0.001)$ and abundance (Chisq $=8.293 ; \mathrm{P}=0.004)$ of the insect herbivores collected from $E$. suberosum differed from that recorded on $Q$. parviflora. The species richness and abundance were, respectively, $83 \%$ and $85 \%$ higher on Q. parviflora (Fig. 1). The species composition of insect herbivores also differed on the two plant species (Fig. 2, Stress =0.153; ANOSIM: $r=0.068, \mathrm{P}=0.007)$, suggesting a substitution of insect species between host plants. However, this result should be viewed with caution because there is an overlap in the points representing the insect communities on the two plants.

\section{Insect herbivores associated with Erythroxylum suberosum}

The abundance of ants affected the richness and abundance of sucking insects (Table 1). In fact, the plants of

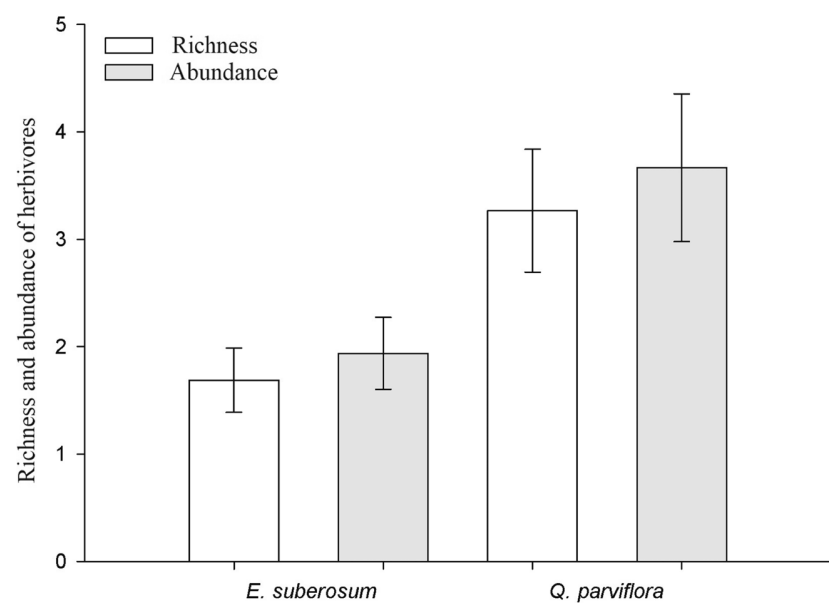

Fig. 1. Average richness and abundance of herbivorous insects collected from Erythroxylum suberosum and Qualea parviflora in an area of Cerrado in Brazil. 




Fig. 2. Non-Metric MultiDimensional Scaling (nMDS) showing the ordination of insect herbivores collected from Erytroxylum suberosum and Qualea parviflora plants in an area of Cerrado in Brazil.

E. suberosum with the greatest abundance of ants had the greatest richness (Fig. 3A) and abundance (Fig. 3B) of sucking insects. The numbers of chewing insects recorded are not affected by plant richness and ant abundance alone. However, the interaction between the variables plant richness and ant abundance affected the richness and abundance of chewing insects (Table 1). Thus, plants of $E$. suberosum with a low abundance of ants that were located in plots with the greatest plant richness had the greatest richness (Fig. 4A) and abundance (Fig. 4B) of chewing insects.

\section{Insect herbivores associated with Qualea parviflora}

The density of $Q$. parviflora in each plot positively affected the richness (Table 2, Fig. 5A) and the abundance (Table 2, Fig. 5B) of sucking insects associated with this plant. Moreover, the interaction between the variables abundance of ants and abundance of $Q$. parviflora per plot affected the richness and abundance of chewing insect herbivores (Table 2). Again, it is important salient that the explanatory variables (focal plant abundance and ant abundance) alone had no significant effects on chewing insects. The interaction term showed that plants of $Q$. parviflora with low numbers of ants that were in plots where there were few of these plants had the greatest richness (Fig. 6A) and abundance (Fig. 6B) of chewing insects.
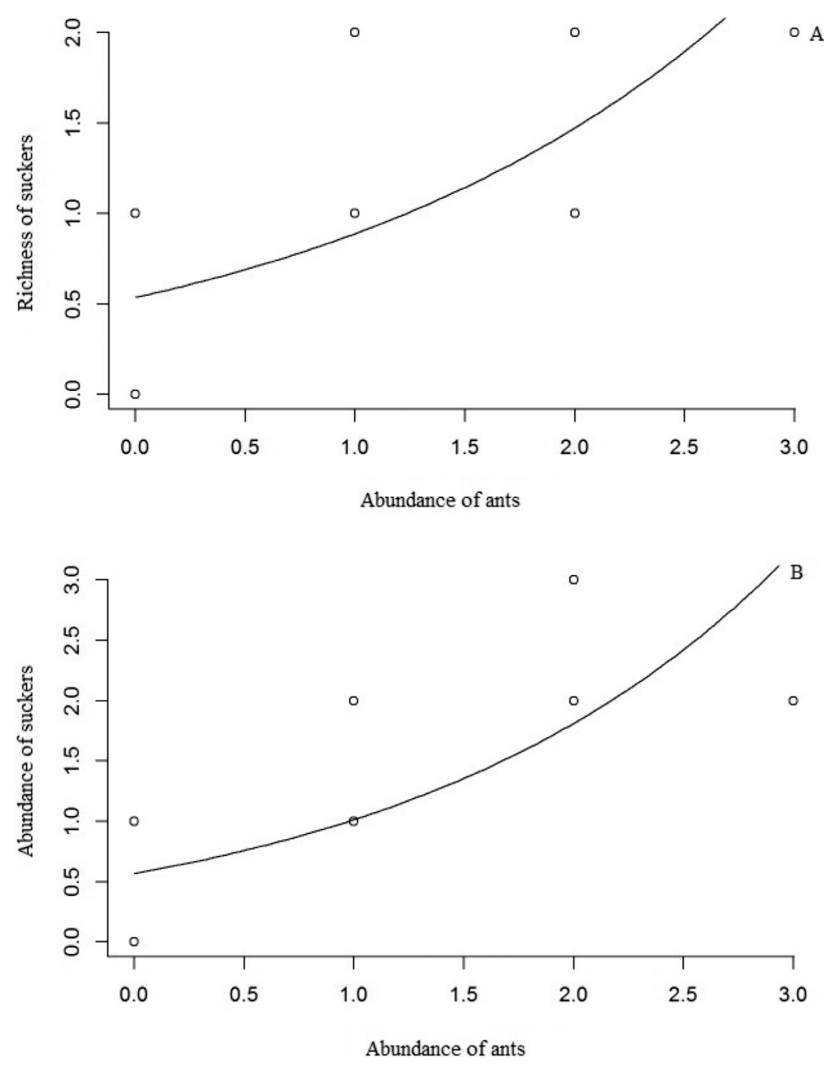

Fig. 3. The relationship between ant abundance and richness (A) and abundance (B) of sucking herbivorous insects associated with Erythroxylum suberosum in an area of Cerrado in Brazil.

\section{DISCUSSION}

In the tropics, insect herbivore communities are characterized by a high richness and low abundance of each species (Price, 1994; Fagundes \& Fernandes, 2011). Recent studies also demonstrate a low population density and frequency of free-living herbivorous insects associated with a specific host plant (Fagundes \& Fernandes, 2011; Neves et al., 2012). This pattern is probably associated with the greater plant diversity and greater herbivore specificity in tropical environments (Dyer et al., 2007). The results of this study corroborate this general pattern of high richness and low abundance of insect herbivores. In addition, the difference in the composition of herbivorous insect communities recorded on Erythroxylum suberosum and Qualea parviflora (but see observation in results) indicate that each species of plant has a specific fauna of insect herbivores,

Table 1. Minimum adequate models showing the effects of the explanatory variables (total richness of plant species per plot and abundance of ants associated with Erythroxylum suberosum) on the richness and abundance of the herbivorous insects collected from E. suberosum.

\begin{tabular}{|c|c|c|c|c|c|c|}
\hline Response variables & Explanatory variables & Deviance & Df & Resid. dev. & $\mathrm{F}$ & $\mathrm{P}$ \\
\hline Richness of sucking insects & Abundance of ants & 3.9186 & 12 & 8.0988 & 3.9186 & 0.0477 \\
\hline Abundance of sucking insects & Abundance of ants & 6.2007 & 12 & 8.7088 & 6.2007 & 0.0127 \\
\hline \multirow{3}{*}{ Richness of chewing insects } & Abundance of ants & 3.1280 & 13 & 16.392 & 3.1280 & 0.0769 \\
\hline & Richness of plants & 0.0940 & 12 & 16.297 & 0.0940 & 0.7586 \\
\hline & Richness of plants: Abundance of ants & 4.1662 & 11 & 12.131 & 4.1662 & 0.0412 \\
\hline \multirow{3}{*}{ Abundance of chewing insects } & Abundance of ants & 3.1346 & 13 & 21.719 & 3.1346 & 0.0766 \\
\hline & Richness of plants & 0.4529 & 12 & 21.266 & 0.4529 & 0.5009 \\
\hline & Richness of plants: Abundance of ants & 4.7466 & 11 & 16.520 & 4.7466 & 0.0244 \\
\hline
\end{tabular}



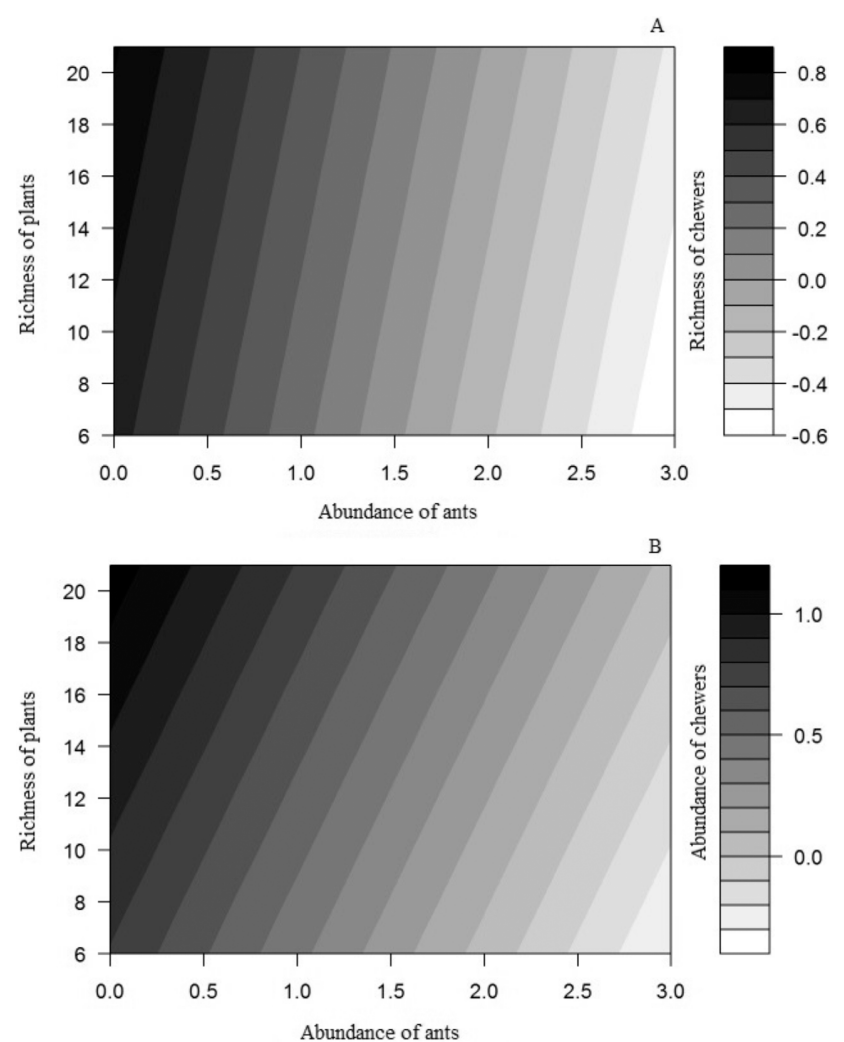

Fig. 4. The effects of the interaction between abundance of ants collected on Erythroxylum suberosum and plant species richness per plot on the richness $(A)$ and abundance $(B)$ of chewing herbivorous insects associated with $E$. suberosum in an area of Cerrado in Brazil.

which is reflected in the high $\beta$ diversity between plant species. Thus, one can expect that a high plant diversity associated with differences in the insect composition recorded on different species of plants generates the pattern of low density of herbivores per plant and high total diversity.

The composition of the insect herbivore families recorded in this study also corroborates the general pattern of insect diversity described for other tropical regions. Commonly, Chrysomelidae, Cicadelidae and Curculionidae are considered to be important herbivorous insects (Basset, 2001; Neves et al., 2011). Since these families are among the most abundant in tropical environments (Campos et al., 2006; Costa et al., 2011) it is not surprising that we recorded them in this study.
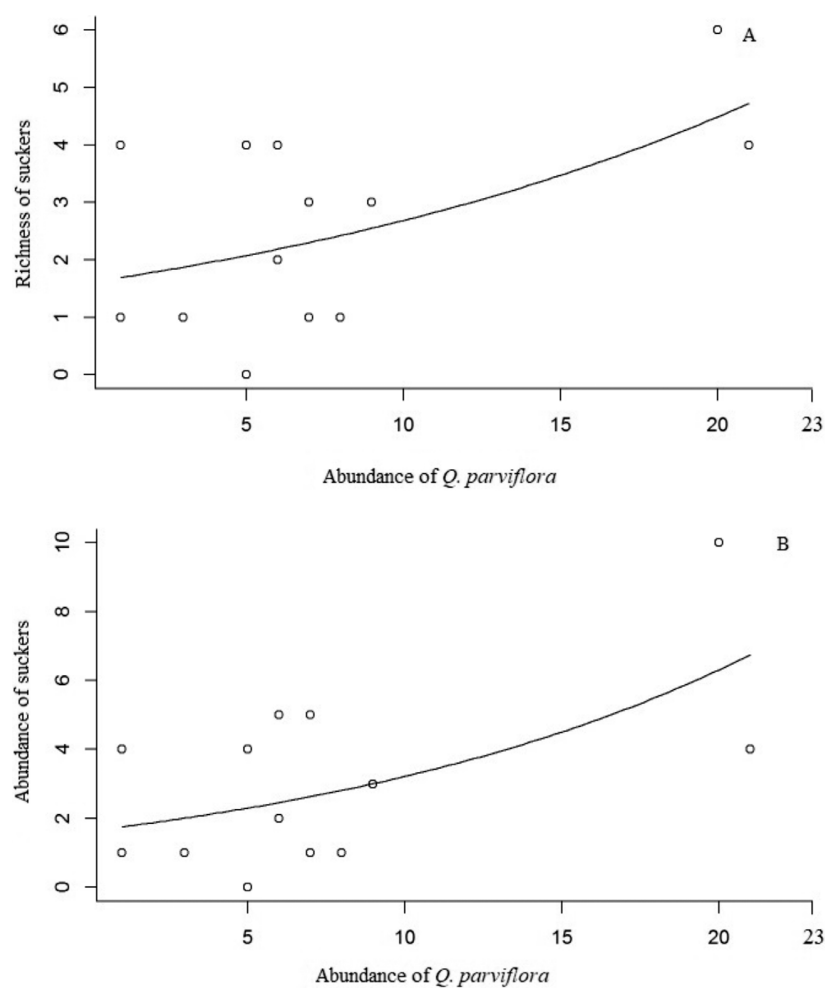

Fig. 5. The relationship between the abundance of Qualea parviflora per plot and the richness (A) and abundance (B) of sucking herbivorous insects collected from Q. parviflora in an area of Cerrado in Brazil.

The richness and abundance of insect herbivores were higher on $Q$. parviflora than on E. suberosum. There are six tropical genera in the family Vochysiaceae (Souza, 2014), whereas in the family Erythroxylaceae there is only the genus Erythroxylym in the neotropical region (Plowman \& Hensold, 2004). Furthermore, Q. parviflora is considered to be the second most common woody species in the Brazilian Cerrado (Ratter et al., 2003). In this study, Q. parviflora made up $22.46 \%$ of all the plants present in the plots sampled, while E. suberosum represented 9.11\% (Appendix 1). Therefore, the greater diversity of herbivores recorded on $Q$. parviflora can be explained by both the hypothesis of taxonomic isolation (Owen \& Whiteway, 1980) and of geographical area (Southwood, 1960). These hypotheses predict, respectively, that plant species belonging to large taxonomic groups and with a broad geographical distribution have a greater diversity of associated herbivores.

Table 2. Minimum adequate models showing the effects of the explanatory variables (abundance of Qualea parviflora per plot and abundance of ants collected from Q. parviflora) on the richness and abundance of herbivorous insects associated with Q. parviflora.

\begin{tabular}{lcrrrrc}
\hline Response variables & Explanatory variables & Deviance & Df & Resid. dev. & $\mathrm{F}$ & $\mathrm{P}$ \\
\hline Richness of sucking insects & Abund. of Q. parviflora & 3.8793 & 12 & 13.799 & 3.8793 & 0.0488 \\
\hline Abundance of sucking insects & Abund. of Q. parviflora & 8.4839 & 12 & 20.108 & 8.4839 & 0.0036 \\
\hline & Abund. of ants & 0.6882 & 12 & 15.938 & 0.6882 & 0.4067 \\
Richness of chewing insects & Abund. of Q. parviflora & 0.1400 & 11 & 15.798 & 0.1400 & 0.7082 \\
& Richness of plants & 1.5020 & 10 & 14.296 & 1.5020 & 0.2202 \\
& Abund. of ants: Abund. of Q. parviflora & 8.6220 & 9 & 5.674 & 8.6220 & 0.0033 \\
\hline & Abund. of ants & 1.2100 & 12 & 17.269 & 1.2100 & 0.2713 \\
Abundance of chewing insects & Abund. of Q. parviflora & 0.3650 & 11 & 16.897 & 0.3650 & 0.5433 \\
& Richness of plants & 1.2230 & 10 & 15.673 & 1.2230 & 0.2687 \\
& Abund. of ants: Abund. of Q. parviflora & 8.0390 & 9 & 7.634 & 8.0390 & 0.0040 \\
\hline
\end{tabular}



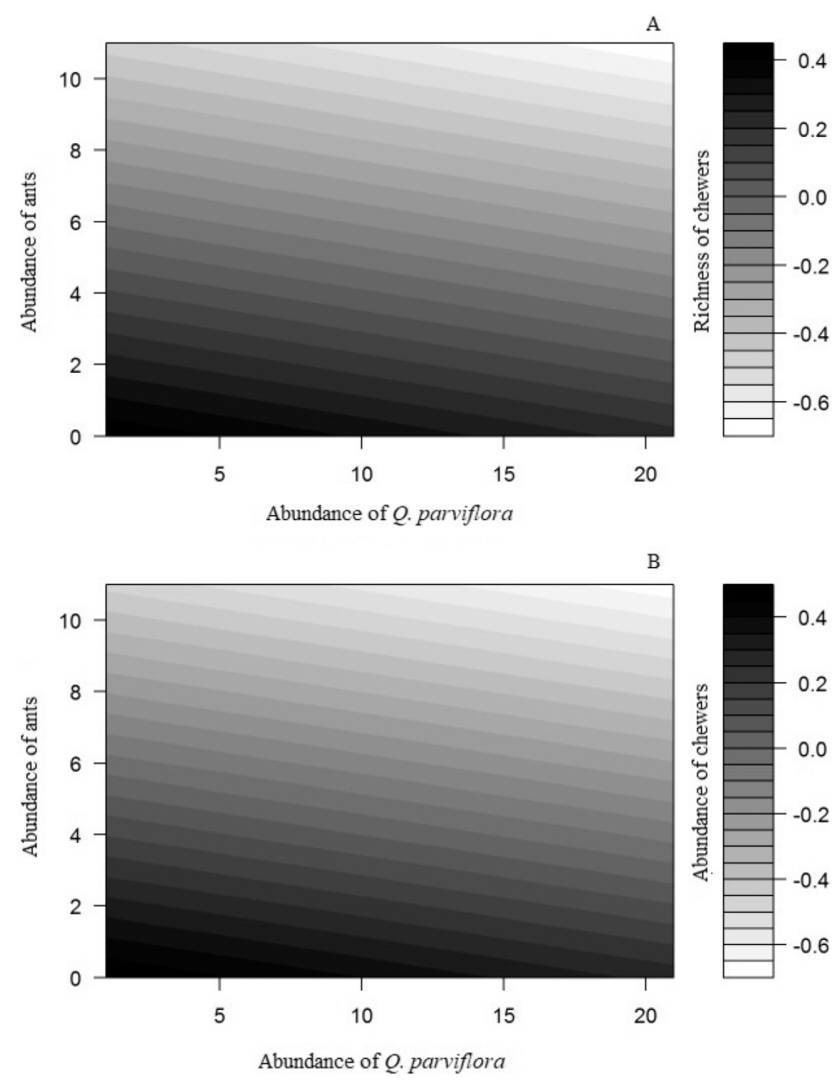

Fig. 6. The effects of the interaction between the abundance of Qualea parviflora per plot and abundance of ants on the richness (A) and abundance (B) of chewing herbivorous insects collected from Q. parviflora in an area of Cerrado in Brazil.

Contrary to our initial hypothesis, the abundance and the richness of sucking insects associated with E. suberosum was positively associated with the abundance of ants. The interaction between ants and herbivores is very variable (Bronstein, 1998; Fraser et al., 2001; Michelangeli, 2003). For example, there is a greater abundance of ants on plants infested with Homoptera that secrete honeydew, but these ants can also prey on or deter other herbivorous insect that feed on the same plant (Del-Claro, 2004; Rosumek et al., 2009). Our results indicate that $11 \%$ of the insect herbivores that were collected from E. suberosum belong to families that include species that produce honeydew (Aphididae, Thyreocoridae and Cicadelidae). Therefore, these herbivores might attract ants to plants and account for the positive relationship between sucking insect diversity and abundance of ants recorded on E. suberosum.

Our results also indicate that the richness and abundance of chewing herbivores were lower on plants of E. suberosum with few ants located in plots with a greater diversity of plants. The negative effect of ants on the abundance of chewing insects is a relatively common phenomenon (eg. Gibb, 2003; Cross, 2016; Styrsky \& Eubanks, 2007). In addition, a positive relationship between plant diversity and the diversity of generalist insect herbivores is also documented (Ricklefs \& Marquis, 2012). In this context, it is reasonable to expect that the probability of finding a generalist insect herbivore in a plot increases with increasing plant richness per plot. Therefore, it is possible to find a large number of chewing insects on plants of $E$. suberosum with few ants located in plots with a high plant richness.

The richness and abundance of sucking insects associated with Qualea parviflora were affected only by the abundance of the host plant. Some studies show that the diversity of herbivorous specialists is positively associated with the abundance of the host plant (Blanche \& Ludwig, 2001; Cuevas-Reyes et al., 2004; Araújo et al., 2013). The resource concentration hypothesis (Root, 1973) has been used to account for this pattern. According to this hypothesis, herbivore specialists locate big patches of resource more easily and remain in these patches for a longer because the resource is more abundant (Souza \& Fagundes, 2017). Thus, individuals of $Q$. parviflora located in plots where this plant is abundant should have greater diversity of sucking herbivores, as observed in this study.

Similar to what was observed on E. suberosum, the richness and abundance of chewing insects associated with $Q$. parviflora are affected by the interaction between top-down and bottom-up forces. In fact, the richness and abundance of chewing insects was higher on plants of $Q$. parviflora with low numbers of ants and located in plots where the abundance of this plant is low. Again, generalist predators seem to play a negative role in the diversity of chewing herbivores on this plant. In addition, the negative response of chewing insect diversity to the abundance of the host plant could be associated with the high density of the plant. In this case, the local pool of herbivores could be partitioned between the two plants studied, resulting in the negative relationship between the numbers of herbivores per plants and abundance of each plant (see also, Otway et al., 2005; Souza \& Fagundes, 2017). However, it is important that only the combination of these explanatory variables (i.e. abundances of ant and $Q$. parviflora plants) affected the richness and abundance of chewing herbivores on plants of $Q$. parviflora.

Finally, this study indicates that the diversity of insect herbivores on the two host plants differ. Moreover, the variation in the composition of herbivorous insects recorded indicates a substitution of herbivorous insect among host plants and can help explain the high diversity of insect herbivores in the tropics. Our results also indicate that top-down and bottom-up forces can act jointly to shape the organization of insect herbivore communities. For example, the effect of generalist predators on the diversity of chewing herbivores associated with the host plants $Q$. parviflora and E. suberosum is dependent on interactions between the abundance of these plants and total plant richness, respectively. In addition, the effect of ants on herbivorous insects can be guild-dependent. In fact, the guild of generalist herbivores was negatively affected by ants, while the top-down effect on the sucking insect guild were less consistent and dependent on the trophobosis between homopterans and ants.

ACKNOWLEDGEMENTS. The authors would like to thank the trainees of the Laboratório de Biologia da Conservação of Unimontes for their support during field work and the Laboratório de Mirmecologia (CEPLAC/CEPEC) coordinated by J.H.C. De- 
labie for their help in identifying the insects. The authors also thank the Pos-graduated Program of Biodiversity (PPG-BURN) of Unimontes and the Projeto Jequitaí CODEVASF/SEAPA-MG for logistical support.

\section{REFERENCES}

Abdala-Roberts L., Parra-Tabla V., Salinas-Peba L., DíazCAstelazo \& Delfín-GonzÁles H. 2010: Spatial variation in the strength of a trophic cascade involving Ruellia nudiflora (Acanthaceae), an insect seed predator and associated parasitoid fauna in Mexico. - Biotropica 42: 180-187.

Araújo W.S., Scareli-Santos C., Guilherme F.A.G. \& CuevasReYes P. 2013: Comparing galling insect richness among neotropical savannas: effects of plant richness, vegetation structure and super-host presence. - Biodiv. Conserv. 22: 1083-1094.

BARTón K. 2015: MuMIn: Multi-Model Inference. R Package Ver. 1.15.1. URL: http://CRAN.Rproject.org/package=MuMIn.

BASSET Y. 2001: Invertebrates in the canopy of tropical rain forests: How much do we really know? - Plant Ecol. 153: 87-107.

Blanche K.R. \& Ludwig J.A. 2001: Species richness of gall-inducing insects and host plants along an altitudinal gradient in big bend national park, Texas. - Am. Midl. Nat. 154: 219-232.

Brady S.G., Fisher B.L., Schultz T.R. \& Ward P.S. 2014: The rise of army ants and their relatives: diversification of specialized predatory doryline ants. - BMC Evol. Biol. 14: 93, 14 pp.

BRONSTEIN J.L. 1998: The contribution of ant plant protection studies to our understanding of mutualism. - Biotropica 30: $150-161$.

Campos R.L., Vasconcelos H.L., Ribeiro S.P., Neves F.S. \& SOARES J.P. 2006: Relationship between tree size and insect assemblages associated with Anadenanthera macrocarpa. Ecography 29: 442-450.

Carpenter S.R., Kitchell J.F. \& Hodgson J.R. 1985: Cascading trophic interactions and lake productivity. - BioScience 35: 634-639.

Coelho M.S., Carneiro M.A.A., Branco C.A., Borges R.A.X., Fernandes G.W. 2017: Galling insects of the Brazilian Páramos: species richness and composition along high-altitude grasslands. - Environ. Entomol. 46: 1243-1253.

Cornelissen T., Guimarães C.D.C., Viana J.P.R. \& Silva B. 2013: Interspecific competition influences the organization of a diverse sessile insect community. - Acta Oecol. 52: 15-18.

Costa F.V., Neves F.S., de Oliveira J.S. \& Fagundes M. 2011: Relationship between plant development, tannin concentration and insects associated with Copaifera langsdorffii (Fabaceae). - Arthropod-Plant Interact. 5: 9-18.

Costa F.V., Queiroz A.C.M., Maia M.L.B., Reis-Júnior R. \& FAGUNDES M. 2016: Resource allocation in Copaifera langsdorffii (Fabaceae): how supra-annual fruiting affects plant traits and herbivory? - Rev. Biol. Trop. 64: 507-520.

Cross S.L., Cross A.T., Merritt D.J., Dixon K.W. \& Andersen A.N. 2016: Biodiversity responses to vegetation structure in a fragmented landscape: ant communities in a peri-urban coastal dune system. - J. Insect Conserv. 20: 485-495.

Cuevas-Reyes P., Quesada M., Hanson P., Dirzo R. \& Oyama K. 2004: Diversity of gall-inducing insects in a Mexican tropical dry forest: the importance of plant species richness, life-forms, host plant age and plant density. - J. Ecol. 92: 707-716.

Davidson D.W., Coоk S.C., Snelling R.R. \& Chua T.H. 2003: Explaining the abundance of ants in lowland tropical rainforest canopies. - Science 300: 969-972.
Del-Claro K. 2004: Multitrophic relationships, conditional mutualisms, and the study of interaction biodiversity in tropical savannas. - Neotrop. Entomol. 33: 665-672.

Del-Claro K., Berto V. \& Reu W. 1996: Effect of herbivore deterrence by ants on the fruit set of an extrafloral nectary plant, Qualea multiflora (Vochysiaceae). - J. Trop. Ecol. 12: 887892.

Dyer L.A. \& Letourneau D.K. 1999: Relative strengths of topdown and bottom-up forces in a tropical forest community. Oecologia 119: 265-274.

Dyer L.A., Singer M.S., Lill J.T., Stireman J.O., Gentry G.L., Marquis R.J., Ricklefs R.E., Greeney H.F., Wagner D.L., MoRAIS H.C. ET AL. 2007: Host specificity of Lepidoptera in tropical and temperate forests. - Nature 448: 696-699.

FAGUndes M. \& Fernandes G.W. 2011: Insect herbivores associated with Baccharis dracunculifolia (Asteraceae): responses of gall-forming and free-feeding insects to latitudinal variation. - Rev. Biol. Trop. 59: 1419-1432.

Fagundes M., Neves F.S. \& Fernandes G.W. 2005: Direct and indirect interactions involving ants, insect herbivores, parasitoids, and the host plant Baccharis dracunculifolia (Asteraceae). - Ecol. Entomol. 30: 28-35.

Fernandes G.W., Pedroni F., Sanchez M., Scariot A., Aguiar L.M.S., Ferreira G., Machado R., Ferreira M.E., Diniz S., Pinheiro R. et AL. 2016: Cerrado: Em Busca de Soluções Sustentáveis. EditoraVozes, Rio de Janeiro, 211 pp.

Forister M.L., Novotny V., Panorska A.K., Baje L., Basset Y., Butterill P.T., Cizek L., Coley P.D., Dem F., Diniz I.R. et AL. 2015: The global distribution of diet breadth in insect herbivores. - Proc. Natl. Acad. Sci. 112: 442-447.

Fraser A.M., AxÉn A.H. \& Pierce N.E. 2001: Assessing the quality of different ant species as partners of a myrmecophilous butterfly. - Oecologia 129: 452-460.

GiBB H. 2003: Dominant meat ants affect only their specialist predator in a complex natural system. - Oecologia 136: 609-615.

Grandez-Rios M., Bergamini L.M., Araújo W.S., Villalobos F. \& Almeida-Neto M. 2015: The effect of host-plant phylogenetic isolation on species richness, composition and specialization of insect herbivores: A comparison between native and exotic hosts. - PLOS ONE 10: e0138031, 14 pp.

Grimbacher P.S. \& STORK N.E. 2007: Vertical stratification of feeding guilds and body size in beetle assemblages from an Australian tropical rainforest. - Austral Ecol. 32: 77-85.

Hammer Ø., Harper D.A.T. \& Ryan P.D. 2001: PAST - Palaeontological Statistics. - Palaeontol. Eelectron. 4: 4, 9 pp.

Heil M. \& McKey D. 2003: Protective ant-plant interactions as model systems in ecological and evolutionary research. Annu. Rev. Ecol. Evol. Syst. 34: 425-453.

Hoog B. \& DAANE K. 2015: Impacts of exotic spider spillover on resident arthropod communities in a natural habitat. - Ecol. Entomol. 40: 69-77.

INMET (Instituto Nacional de Meteorologia) 2016: URL: http:// www.inmet.gov.br/ portal. Last accessed in September, 2016.

KAPLAN I. \& DENNO R.F. 2007: Interspecific interactions in phytophagous insects revisited: a quantitative assessment of competition theory. - Ecol. Lett. 10: 977-994.

LÁzaro-GonzÁlez A., Hódar J.A. \& Zamora R. 2017: Do the arthropod communities on a parasitic plant and its hosts differ? - Eur. J. Entomol. 114: 215-221.

Leal C.R.O., Fagundes M. \& Neves F.S. 2015: Change in herbivore insect communities from adjacent habitats in a transitional region. - Arthropod-Plant Interact. 9: 311-320. 
Lin Y.P., Cook D.H., Gullan P.J. \& CooK L.G. 2015: Does host plant diversity explain species richness in insects? A test using Coccidae (Hemiptera). - Ecol. Entomol. 40: 299-306.

McCoy E.D., Bell S.S. \& Mushinsky H.R. 1991: Habitat structure: synthesis and perspectives. In Bell S.S., McCoy E.D. \& Mushinsky H.R. (eds): Habitat Structure: The Physical Arrangement of Objects in Space. Chapman and Hall, New York, pp. $427-430$

Michelangeli F.A. 2003: Ant protection against herbivory in three species of Tococa (Melastomataceae) occupying different environments. - Biotropica 35: 181-188.

Mody K. \& Linsenmair K.E. 2004: Plant attracted ants affect arthropod community structure but not necessarily herbivory. Ecol. Entomol. 29: 217-225.

Moon D.L.C. \& SiLva D. 2013: Environmental heterogeneity mediates a cross-ecosystem trophic cascade. - Ecol. Entomol. 38: $23-30$.

Myers N., Mittermeier R.A., Mittermeier C.G., Fonseca G.A. \& KENT J. 2000: Biodiversity hotspots for conservation priorities. - Nature 403: 853-858

Nascimento A.R., Almeida-Neto M., Almeida A.M., Fonseca C.R., Lewinsohn T.M. \& Penteado D.A. 2015: Disentangling the influence of plants and herbivores on the local diversity of parasitoids in the Brazilian Cerrado. - Insect Conserv. Diver. 8: $313-321$.

Neves F.S., Araújo L.S., Fagundes M., Espírito-Santo M.M., Fernandes G.W., SÁnchez-Azofeifa G.A. \& Quesada M. 2010: Canopy herbivory and insect herbivore diversity in a dry forest-savanna transition in Brazil. - Biotropica 42: 112-118.

Neves F.S., Fagundes M. Sperber C.F. \& Fernandes G.W. 2011: Tri-trophic level interactions affect host plant development and abundance of insect herbivores. - Arthropod-Plant Interact. 5: $351-357$

Neves F.S., Braga R.F., Araujo L.S., Campos R.I. \& Fagundes M. 2012: Differential effects of land use on ant and herbivore insect communities associated with Caryocarbrasiliense (Caryocaraceae). - Rev. Biol. Ttrop. 60: 1065-1073.

Neves F.S., Sperber C.F., Campos R.I., Soares J.P. \& Ribeiro S.P 2013: Contrasting effects of sampling scale on insect herbivores distribution in response to canopy structure. - Rev. Biol. Trop. 61: 125-137.

Neves F.S., Silva J.O., Espírito-Santo M.M. \& Fernandes G.W. 2014: Insect herbivores and leaf damage along successional and vertical gradients in a tropical dry forest. - Biotropica 46: $14-24$.

Novotny V., Basset Y., Miller S.E., Drozd P. \& Cizek L. 2002: Host specialization of leaf chewing insects in a New Guinea rainforest. - J. Anim. Ecol. 71: 400-412.

Novotny V., Basset Y. \& Kitching R.L. 2003: Herbivore assemblages and their food resources. In Basset Y., Novotny V., Miller S.E. \& Kitching R.L. (eds): Arthropods of Tropical Forests: Spatio-Temporal Dynamics and Resource Use in the Canopy. Cambridge University Press, Cambridge, pp. 40-58.

Novotny V., Drozd P., Miller S.E., Kulfan M., Janda M., BasSET Y. \& WeIBLEN G.D. 2006: Why are there so many species of herbivorous insects in tropical rainforests? - Science 313: $1115-1118$

Otway S.J., Hector T.A. \& Lawton J.H. 2005: Resource dilution effects on specialist insect herbivores in a grassland biodiversity experiment. - J. Anim. Ecol. 74: 234-240.

OWen D.F. \& Whiteway W.R. 1980: Buddleia davidii in Britain: history and development of an associated fauna. - Biol. Conserv. 17: 149-155.

PAINE R.T. 1980: Food webs: linkage, interaction strength and community infrastructure. - J. Anim. Ecol. 49: 667-685.
Plowman T.C. \& Hensold N. 2004: Names, types and distribution of neotropical species of Erythroxylum (Erythroxylaceae). Brittonia 56: 1-53.

Prather C.M., Pelini S.L., Laws A., Rivest E., Woltz M., Bloch C.P., Del Toro I., Ho C.K., Kominoski J., Newbold T.A., PARSONS S. \& JOERN A. 2013: Invertebrates, ecosystem services and climate change. - Biol. Rev. 88: 327-348.

PrICE P.W. 1994: Phylogentic constraints, adaptive syndromes, and emergent properties: From individuals to population dynamics. - Res. Popul. Ecol. 36: 3-14.

R Development Core Team 2015: $R$ : A Language and Environment for Statistical Computing. R Foundation for Statistical Computing, Vienna. URL: http://www. R-project.org/.

Ratter J.A., Bridgewater S. \& Ribeiro J.F. 2003: Analysis of the floristic composition of the Brazilian cerrado vegetation III: comparison of the woody vegetation of 376 areas. - Edinburgh J. Bot. 60: 57-109.

Ribas C.R., Schoereder J.H., Pic M. \& Soares S.M. 2003: Tree heterogeneity, resource availability, and larger scale processes regulating arboreal ant species richness. - Austral Ecol. 28: 305-314.

RibeIRo S.P. 2003: Insect herbivores in the canopies of savannas and rainforests. In Basset Y., Novotny V., Miller S.E. \& Kitching R.L. (eds): Arthropods of Tropical Forests: Spatio-Temporal Dynamics and Resource Use in the Canopy. Cambridge University Press, Oxford, pp. 348-364.

Richards L.A., Dyer L.A., Forister M.L., Smilanicha C.D., Leonard M.D. \& Jefreey C.F. 2015: Phytochemical diversity drives plant-insect community diversity. - Proc. Natl. Acad. Sci. 112: 10973-10978.

RickLEFS R.E. \& MARQUIS R.J. 2012: Species richness and niche space for temperate and tropical folivores. - Oecologia 168: 213-220.

Rоот R.B. 1973: Organization of a plant arthropod association in simple and diverse habitats: the fauna of collards (Brassica oleracea). — Ecol. Moonogr. 43: 95-124.

Rosumek F.B., Silveira F.A., Neves F.S., Barbosa N.P., Diniz L., Oki Y., Pezzini F., Fernandes G.W. \& Cornelissen T. 2009: Ants on plants: a meta-analysis of the role of ants as plant biotic defenses. - Oecologia 160: 537-549.

SaJo M.G. \& Rudall P.J. 2002: Leaf and stem anatomy of Vochysiaceae in relation to subfamilial and suprafamilial systematics. — Bot. J. Linn. Soc. 138: 339-364.

Scherber C., Eisenhauer N., Weisser W., Schmid B., Voigt W., Fischer M., Schulze E.-D., Roscher C., Weigelt A., Allan E. ET AL. 2010: Bottom-up effects of plant diversity on multitrophic interactions in a biodiversity experiment. - Nature 468: $553-556$.

Shimizu G.H. 2009: Vochysiaceae na Serra do Cipó, Minas Gerais, Brasil. PhD Thesis, Universidade Estadual de Campinas, Campinas, $162 \mathrm{pp}$.

Silva J.M.C. \& BAtES J.M. 2002: Biogeographic patterns and conservation in the South American Cerrado. - BioScience 52: $225-234$.

Southwood T.R.E. 1960: The flight activity of Heteroptera. Trans. R. Entomol. Soc. Lond. 112: 173-220.

SouZA L.F.D. 2014: A família Vochysiaceae A. St.-Hil. na microrregião sudoeste goiano. - Rev. Biol. Neotrop. 11: 1-10.

SouzA M.L. \& FAgundes M. 2017: Seed predation of Copaifera langsdorffii (Fabaceae): a tropical tree with supra-annual fruiting. - Plant Species Biol. 32: 66-73.

Strassburg B.B., Brooks T., Feltran-Barbieri R., Iribarrem A., Crouzeilles R., Loyola R., Latawiec A.E., Oliveira Filho F.J.B., de M. Scaramuzza C.A., Scarano F.R., Soares-Filho 
B. \& BALmford A. 2017: Moment of truth for the Cerrado hotspot. - Nat. Ecol. Evol. 1: 0099, 3 pp.

STYRSKY J.D. \& EubanKs M.D. 2007: Ecological consequences of interactions between ants and honeydew-producing insects. Proc. R. Soc. Lond. (B) 274: 151-164.

Vega X., Grez A.A. \& Simonetti A.A. 2012: Is top-down control by predators driving insect abundance and herbivory rates in fragmented forests? - Austral Ecol. 37: 836-844.
Weisser W.W. \& Siemann E. 2004: The various effects of insects on ecosystem functioning. In Weisser W.W. \& Siemann E. (eds): Insects and Ecosystem Function. Springer, Berlin, Heidelberg, pp. 3-24.

WILSON E.O. 1987: The little things that run the world: the importance and conservation of invertebrates. - Conserv. Biol. 1: $344-346$.

Received December 7, 2017; revised and accepted June 15, 2018 Published online July 20, 2018

Table S1. Abundance (number of individual per species) and frequency (percent of plots that each plant species occur) of plant species sampled in a Cerrado area of Brazil.

\begin{tabular}{|c|c|c|c|}
\hline Family & Species & Abundance & Frequency \\
\hline Anacardiaceae & Astronium fraxinifolium Schott & 15 & 0.31 \\
\hline Annonaceae & Annona dioica A. Saint-Hilaire & 1 & 0.06 \\
\hline Apocynaceae & Aspidosperma tomentosum Martius & 16 & 0.41 \\
\hline Apocynaceae & Himatanthus obovatus (Müll. Arg.) Woodson & 1 & 0.06 \\
\hline Asteraceae & Eremanthus sp. & 1 & 0.06 \\
\hline Bignoniaceae & Handroanthus ochraceus (Cham.) Mattos & 2 & 0.12 \\
\hline Caryocaraceae & Caryocar brasiliense A. Saint-Hilaire & 4 & 0.25 \\
\hline Calophyllaceae & Kielmeyera coriacea Martius & 1 & 0.06 \\
\hline Connaraceae & Connarus suberosus Planch. & 2 & 0.12 \\
\hline Dilenaceae & Curatella americana Linnaeus & 17 & 0.31 \\
\hline Dilenaceae & Davilla elliptica A. Saint-Hilaire & 6 & 0.19 \\
\hline Erythroxylaceae & Erythroxylum suberosum A. Saint-Hilaire & 43 & 1.00 \\
\hline Leguminosae & Acosmium dasycarpum (Vogel) Yakovlev & 39 & 0.69 \\
\hline Leguminosae & Acosmium subelegans (Mohlenbr.) Yakovlev & 2 & 0.06 \\
\hline Leguminosae & Copaifera oblongiolia Martius & 1 & 0.06 \\
\hline Leguminosae & Dimorphandra mollis Bentham & 8 & 0.19 \\
\hline Leguminosae & Dipteryx alata Voguel & 1 & 0.06 \\
\hline Leguminosae & Enterolobium gummiferum (Mart.) J.F. Macbr. & 2 & 0.12 \\
\hline Leguminosae & Hymenaea courbaril Linnaeus & 10 & 0.31 \\
\hline Leguminosae & Hymenaea stigonocarpa Hayne & 3 & 0.06 \\
\hline Leguminosae & Machaerium acutifolium Vogel & 5 & 0.12 \\
\hline Leguminosae & Machaerium opacum Vogel & 1 & 0.06 \\
\hline Leguminosae & Plathymenia reticulata Bentham & 46 & 0.62 \\
\hline Leguminosae & Sclerolobium aureum (Tul.) Baill. & 2 & 0.12 \\
\hline Leguminosae & Smartzia sp. & 1 & 0.06 \\
\hline Leguminosae & Stryphnodendron adstringens (Mart.) Coville & 2 & 0.12 \\
\hline Lythraceae & Lafoensia pacari A. Saint-Hilaire & 5 & 0.12 \\
\hline Malpighiaceae & Byrsonima crassifolia (L.) Kunth & 9 & 0.56 \\
\hline Malpighiaceae & Heteropterys byrsonimifolia A. Juss. & 6 & 0.19 \\
\hline Malvaceae & Eriotheca pubescens (Mart. \& Zucc.) Schott \& Endler & 8 & 0.37 \\
\hline Myrtaceae & Eugenia dysenterica de Candolle & 40 & 0.56 \\
\hline Myrtaceae & Myrciaria floribunda (H. West ex Willd.) O. Berg & 3 & 0.06 \\
\hline Nictaginaceae & Guapira sp. & 7 & 0.37 \\
\hline Opiliaceae & Agonandra brasiliensis Miers ex Bentham & 1 & 0.06 \\
\hline Polygonaceae & Coccoloba sp. & 6 & 0.37 \\
\hline Proteaceae & Roupala montana Aubl. & 4 & 0.12 \\
\hline Sapindaceae & Magonia pubescens A. Saint-Hilaire & 8 & 0.25 \\
\hline Sapotaceae & Pouteria ramiflora (Mart.) Radlk. & 1 & 0.06 \\
\hline Sapotaceae & Pouteria torta (Mart.) Radlk. & 2 & 0.12 \\
\hline Simaroubaceae & Simarouba versicolor A. Saint-Hilaire. & 2 & 0.06 \\
\hline Vochysiaceae & Callisthene fasciculata Martius & 9 & 0.19 \\
\hline Vochysiaceae & Callisthene major Martius & 11 & 0.19 \\
\hline Vochysiaceae & Qualea grandiflora Martius & 8 & 0.19 \\
\hline Vochysiaceae & Qualea parviflora Martius & 106 & 1.00 \\
\hline Vochysiaceae & Salvertia convallariodora A. Saint-Hilaire & 3 & 0.19 \\
\hline Vochysiaceae & Vochysia elliptica Martius & 1 & 0.06 \\
\hline Total & & 472 & \\
\hline
\end{tabular}


Table S2. Relative abundance and frequency of ant species collected from Erythroxylum suberosum and Qualea parviflora in a Cerrado area of Brazil.

\begin{tabular}{|c|c|c|c|}
\hline Subfamily & Species & Abundance & Frequency \\
\hline Dolichoderinae & Azteca sp. & 1.41 & 6.25 \\
\hline \multirow[t]{4}{*}{ Formicinae } & Brachymyrmex admotus Mayr & 16.90 & 18.75 \\
\hline & Camponotus blandus (Smith) Forel & 18.31 & 37.50 \\
\hline & Camponotus novogranadensis Mayr & 4.22 & 12.50 \\
\hline & Camponotus sp. & 1.41 & 6.25 \\
\hline \multirow[t]{3}{*}{ Pseudomyrmecinae } & Pseudomyrmex gracilis Fabricius & 2.82 & 12.50 \\
\hline & Pseudomyrmex simplex Smith & 1.41 & 6.25 \\
\hline & Pseudomyrmex termitaria Smith & 1.41 & 6.25 \\
\hline \multirow[t]{4}{*}{ Myrmicinae } & Cephalotes pusillus Klug & 11.27 & 18.75 \\
\hline & Crematogaster erecta Mayr & 2.82 & 12.50 \\
\hline & Crematogaster victim Smith & 36.62 & 25.00 \\
\hline & Pheidole diligens & 1.41 & 6.25 \\
\hline
\end{tabular}

Table S3. Richness and abundance (numbers in parenthesis) of sucking and chewing insects herbivorous collected from two host plant Erythroxylum suberosum and Qualea parviflora in each spots (S1-S16) in a Cerrado area of Brazil.

\begin{tabular}{|c|c|c|c|c|c|c|c|c|c|c|c|c|c|c|c|c|c|c|}
\hline Guild & Taxa & $\mathrm{S} 1$ & S2 & S3 & S4 & S5 & S6 & S7 & S8 & S9 & $\mathrm{S} 10$ & $\mathrm{~S} 11$ & $\mathrm{~S} 12$ & $\mathrm{~S} 13$ & S14 & $\mathrm{S} 15$ & $\mathrm{~S} 16$ & Total \\
\hline \multirow[t]{13}{*}{ Sucking } & Aphididae & & $1(2)$ & & & & & & & & & & & & & & & $1(2)$ \\
\hline & Cecidomyidae & $1(1)$ & & & & & & & & & & & & & & & & $1(1)$ \\
\hline & Cicadelidae & & $2(2)$ & $1(1)$ & $3(3)$ & $3(6)$ & $1(1)$ & $3(4)$ & $3(4)$ & $12(66)$ & & $2(2)$ & $1(1)$ & & & $1(1)$ & & $32(91)$ \\
\hline & Derbidae & & & & & & & & & & & & & & $1(1)$ & & & $1(1)$ \\
\hline & Fulgoromorpha & $1(1)$ & & & & & & & & & & & & & & & & $1(1)$ \\
\hline & Hemiptera & & & & $1(1)$ & $1(1)$ & & & $1(1)$ & & $2(2)$ & & & & $1(1)$ & & 1(1) & $7(7)$ \\
\hline & Mesoveliidae & & & & & & & & & & & & & & & $1(1)$ & & $1(1)$ \\
\hline & Unidentify & & & & & & & $1(1)$ & & & & & & & & & & $1(1)$ \\
\hline & Pentatomiidae & $1(1)$ & & & & & & & & & & & & & & & & $1(1)$ \\
\hline & Sisyridae & & & & & & & & $1(1)$ & & & & & & & & & $1(1)$ \\
\hline & Thyreocoridae & & & & & & $1(1)$ & & & & & & & & & & & $1(1)$ \\
\hline & Tingidae & $1(1)$ & & & & & & & $1(4)$ & 1(1) & & $1(1)$ & & $2(2)$ & & & & $6(9)$ \\
\hline & Total & $4(4)$ & $3(4)$ & $1(1)$ & $5(5)$ & $4(7)$ & $2(2)$ & $4(5)$ & $7(11)$ & $15(69)$ & $2(2)$ & $4(4)$ & $1(1)$ & $3(3)$ & $2(2)$ & $4(4)$ & $1(1)$ & $54(117)$ \\
\hline \multirow[t]{19}{*}{ Chewing } & Acrididae & & & $1(1)$ & & & & & & & & & & & & & & $1(1)$ \\
\hline & Anobiidae & & & & & & & & & & & & & & $1(1)$ & & & $1(1)$ \\
\hline & Bostrichidae & & & & & & & & & & $1(1)$ & & & & & & & $1(1)$ \\
\hline & Bruchidae & & & & & & & & & & & & & & & $1(1)$ & $1(1)$ & $2(2)$ \\
\hline & Chrysomelidae & & & & & & & $1(2)$ & & 1(1) & & & & & & 1(1) & & $3(4)$ \\
\hline & Coleoptera & & & & & & & & & & & & & & & $2(2)$ & & $2(2)$ \\
\hline & Curculionidae & & & $1(1)$ & & & & $1(1)$ & & & & $1(1)$ & & & & & & $3(3)$ \\
\hline & Lepidoptera & & & & $1(1)$ & & & & & $2(2)$ & & $1(1)$ & & $1(1)$ & & $2(2)$ & & $7(7)$ \\
\hline & Lepismatidae & $1(1)$ & & & & & $1(3)$ & & & & $1(1)$ & $1(1)$ & & $1(1)$ & & $1(2)$ & & $6(9)$ \\
\hline & Unidentify & & & & & & & & & & & $1(1)$ & & & & & & $1(1)$ \\
\hline & Orthoptera & & & $1(1)$ & & & & & & & & & & & & & & $1(1)$ \\
\hline & Psocidae & & & & & & & & & & & $1(1)$ & & & & & & $1(1)$ \\
\hline & Psyllipsocidae & & & & $1(1)$ & & & & & & & & & & & & & $1(1)$ \\
\hline & Pteromalidae & & & & $1(1)$ & & & & & & & & & & & & & $1(1)$ \\
\hline & Rhysodidae & & & & & & & & $1(1)$ & & & & & & & & & $1(1)$ \\
\hline & Scirtidae & & & $1(2)$ & & & & & & & & & & & & & & 1(2) \\
\hline & Tettigoniidae & & & & & & & & & & & & $1(1)$ & & & & & $1(1)$ \\
\hline & Trigonidiidae & $1(1)$ & & & & & & & & & & & & & & & & $1(1)$ \\
\hline & Total & $2(2)$ & & $4(5)$ & $2(2)$ & & $1(3)$ & $2(3)$ & $1(1)$ & 1(1) & $2(2)$ & $4(4)$ & $1(1)$ & $1(1)$ & $1(1)$ & $5(6)$ & $1(1)$ & $35(40)$ \\
\hline
\end{tabular}

